\title{
Physical and Biochemical Basis of Resistance in Some Cowpea Varieties against Callosobruchus maculatus (F.)
}

\author{
Shams Fawki ${ }^{*}$, Amany S. Khaled, Hoda M. Abdel Fattah, Mohamed A. Hussein, Mona I. \\ Mohammed and Dalia A.M. Salem \\ Entomology Department, Faculty of Science, Ain Shams University, Abbasiya 11566, Cairo, Egypt
}

\section{A R T I C L E I N F O}

Article history:

Received 17 December 2012

Accepted 11 February 2013

Keywords:

Cowpea weevil;

C. maculates;

Resistance;

Biochemical factors;

Protein fractions;

Anti-nutrient;

Legumes;

Bruchids;

Stored-grain pest control;

Plant inhibitors.

\section{A B S T R A C T}

Four varieties of the cowpea seeds (Local, Dokki331, Kareem7 and Aswany) were screened for their resistance to the bruchid, Callosobruchus maculatus F., a serious pest of stored pulses. Morphological characters like seed coat texture, volume and weight, were not found to be responsible for offering resistance to $C$. maculatus. Data revealed that the female weevil preferred the smooth surface for egg oviposition. The results also showed that Aswany was found to reduce the growth and development of $C$. maculatus, which were indicated by different parameters; larval penetration $\%$, adult emergence $\%$, total developmental time, susceptibility index and growth index. Seeds were analysed for protein profiles (SDS-polyacrylamide gel electrophoresis) to study the chemical basis of resistant to bruchid infestation. A negative correlation was indicated between the seed total protein content and the susceptibility index. SDS-PAGE analysis of seeds protein for the fore mentioned varieties revealed the presence of antinutrient chemicals that might impart resistance to $C$. maculatus. The role of these antinutritionals in relation to $C$. maculatus infestation is discussed.

\section{Introduction}

The cowpea weevil Callosobruchus maculatus (F.) is a major field-to-store pest of many cultivated legumes especially cowpea crop ${ }^{[1-4]}$. It is well known to cause a considerable damage and economic losses to many pulses that makes them unfit for planting or human utilization either as high protein diet or as an animal feed $^{[2,4-9]}$.

Cowpea (Vigna unguiculata (L.) Walpers) is considered as an important source of plant protein for many poor people in the tropic and is a source of income ${ }^{[2]}$. Many studies demonstrated the devastating damage of cowpeas during post-harvest storage caused by the cowpea beetle $C$. maculatus in different regions as well as in Egypt ${ }^{\text {[7, 10-11]. }}$.

Several chemical and non-chemical methods of protecting seeds from bruchid attack are in use among farmers. These methods include using of organic and natural insecticides, exploitation of controlled atmospheres, integration of physical methods such as heating ${ }^{[12]}$, cooling ${ }^{[13]}$ and biological agents such as parasitoids ${ }^{[14]}$. The researchers have been directed to and emphasized on developing safe methods with less or

* Corresponding author.

E-mail address: shfawki@sci.asu.edu.eg no effect on food contamination and environmental pollution ${ }^{[2]}$. One of these methods with a very promising future is using resistant varieties to protect cowpea seeds from $C$. maculatus attack.

As the cowpea beetle $C$. maculatus is one of the most destructive pests for many legumes in Egypt ${ }^{[15]}$, many attempts have been directed to find very simple, easy to use, and not expensive methods to achieve cowpea beetle control in Egypt ${ }^{[7,10]}$. Using improved cowpea varieties has contributed to achieve the suppression of $C$. maculatus population ${ }^{[2,7,10]}$.

Legume seeds have developed chemical defence compounds that protect them against the attack of different insect pests. There are a wide range of these compounds including tunnins, non-protein amino acids and defensive proteins $[15,16-18]$.

The present work was conducted to study different biological aspects of $C$. maculatus and how these parameters would vary between different cowpea varieties. Also, it was aimed to study certain biochemical aspects in the resistant and susceptible cowpea cultivars.

\section{Materials and Methods}

Insect culture and cowpea varieties

A colony of cowpea weevil, Callosobruchus maculatus 
(F.) was obtained from Plant Protection Research Institute, Dokki, Giza, Egypt, where the colony is maintained on cowpea seeds (Vigna unguiculata L. Walpers) over about 15 years. In the current study, adult weevils were maintained on cowpea seeds (Vigna unguiculata $\mathrm{L}$. Walpers) that were obtained from a local store (Cairo, Egypt), and were frozen by keeping at about $-20^{\circ} \mathrm{C}$ for $2-6 \mathrm{~h}$. to disinfest them from any previous stored-grain pests. The adult weevils were kept at room temperature $\left(29 \pm 2^{\circ} \mathrm{C}\right)$, relative humidity of 35 $\pm 5 \%$ and ambient photoperiod of about $16 \mathrm{~L}: 8 \mathrm{D}$.

Four cowpea varieties were screened for resistance, Dokki331 (D), Kareem7 (K), Aswany(A) and a Local one (L) that was also used to maintain the weevil colony. The first three ones were obtained from Horticulture Research Institute, Agriculture Research Centre, Dokki, Giza, Egypt, while the last one was obtained from a local store.

Correlation between physical characters of cowpea seeds varieties and some biological aspects of cowpea weevil $C$. maculatus.

The resistance of tested cowpea seeds to infestation with $C$. maculatus was evaluated by two experiments. The first experiment was conducted to determine the correlation between physical parameters (weight, volume and coat texture) of seeds of each variety and female oviposition performance and larval penetration. For each variety four replicates were designed, each contained $15 \mathrm{~g}$ seeds and one pair of newly emerged adults that were kept in plastic containers. The number of eggs deposited by each female was recorded and the rate of larval penetration into seeds was determined in relation to the seed morphological characters ${ }^{[19]}$.

For seed weight determination 10 seeds from each variety were weighed individually and the average was calculated, while the seed volume was determined using water displacement in a graduated cylinder (10 $\mathrm{ml}$ ). To estimate the seed volume 10 seeds from each variety were also used individually.

In the second experiment conventional screening was used to determine the relative susceptibility of cowpea cultivars based on the following parameters according to Singh and Jackai (cited by 15).

- Total developmental time (TDT) = mean developmental time per insect.

- Growth index (GI) =Ln adult emergence \% / TDT.

- Susceptibility index (SI) $=$ (GI of tested variety/ GI of the host seeds) X 100; where the host seed is the most susceptible one (D) with the highest (GI). Four groups, one for each variety, were designed. For each group newly emerged adult weevils were allowed to lay eggs for only $24 \mathrm{~h}$ on cowpea seeds. After adult removal all groups were kept for 14 days, then seeds of each group with only one penetrated larva were separated individually in Eppendorf tubes $(1.5 \mathrm{ml})$. For each variety, the one larval penetrated seeds were separated into four groups, each with 10 seeds. At end of the experiment, adult emergence percent (\% AE) and total developmental time (TDT) were estimated for each larva/ seed.

For seed moisture content (SMC) measuring, Agrawal ${ }^{[20]}$ method was used. All cowpea seeds of different cultivars were grounded in a mortar then finely grounded in grinding mill. In each group 3-4 replicates were used.

\section{Biochemical studies:}

\section{a) Samples collection}

Samples of four cowpea seeds varieties (Local, Dokki331, Kareem7 and Aswany) were used for biochemical analysis. Each seed variety was grounded with electrical blender to a very fine powder. Each powder sample was homogenized in ice-cold Tris buffer $(1.5 \mathrm{M}$ Tris-Hcl) in sterile glass test tube using glass homogenizer, centrifuged at 10.000 r.p.m. for $10 \mathrm{~min}$. at $4^{\circ} \mathrm{C}$. The supernatants of centrifuged tissue (powder) were withdrawn carefully using automatic pipettes and transferred to a new Eppendorf tube and kept frozen at $70{ }^{\circ} \mathrm{C}$ till used.

\section{b) Total protein measurement}

The total protein concentration of each sample was measured photometrically at $562 \mathrm{~nm}$ and compared with standard of bovine gamma globulin using the Bio-Rad protein assay ${ }^{[21]}$. Results were subjected to analysis of variance using ANOVA one-way as mentioned by Steel and Torrie in ${ }^{[22]}$.

\section{c) Electrophoretic analysis}

Total protein was fractioned by SDS polyacrylamide gel electrophoresis (PAGE) as described by Smith ${ }^{[23]}$; using an acrylamide (10\%) gel. High and low MW standards were used for the determination of protein profiles of all fractionated samples. A gel-pro-analyser (version 3.1 Media Cybernetics USA) was used for the protein analysis of tested samples. A comprehensive computer software application is designed to determine the number of molecular weights and the amount of peptide chains as well as scanned graphical presentation of the fractionated bands of each lane.

\section{Data analysis}

For data analysis, homogeneity of the variances was tested using Levene's test. When the assumption of homogeneity of the variances was fulfilled, one-way ANOVA was applied followed by pairwise comparisons using LSD-test as mentioned by Steel and Torrie in ${ }^{[22]}$. When no transformation was able to homogenise the group variances, Welch ANOVA was applied. After that, pairwise comparisons were made using Thamhane-test. Also, coefficient of correlation analysis between variables was performed if needed using the package SPSS program.

\section{Results and discussion}

Correlation between physical characters of cowpea seeds and larval penetration of $C$. maculatus

The physical characters of cowpea seeds varieties are shown in Table (1). Data revealed that the seed texture of cowpea was an important factor as an oviposition stimulus for $C$. maculatus. The average number of eggs 
laid by female on (A) seeds with smooth surface (79.5 \pm 5.66$)$ was significantly $(P=0.009)$ higher than those deposited on the other seeds with wrinkled coat. The lowest number of eggs $(42.6 \pm 6.25)$ was laid on the seeds of (L) variety followed in order by (D) and (K) $(45.6 \pm 4.95$ and $58.75 \pm 5.5)$ respectively. In agreement with the present results, Sulehrie et al. ${ }^{[24]}$ recorded that genotypes of green- and black-grain (Legmuminosae) seeds with smooth seed coats were preferred for oviposition of C. maculatus. Abdel Fattah and Ahmed [15] indicated that bean seeds with hard wrinkled coat were less preferable for eggs laying than seeds with soft smooth surface.

No significant correlation was obtained between the numbers of laid eggs, seed weight and volume of different cowpea seeds ( $\mathrm{r}=-0.441, P=0.076 ; \mathrm{r}=-0.421$, $P=0.076$, respectively). Among the tested varieties, (A) type had the light and small seed $(0.081 \pm 0.005 \mathrm{~g} / \mathrm{seed})$ received (79.5 \pm 5.66$)$ eggs, while the heaviest large one (D) $(0.243 \pm 0.014 \mathrm{~g} / \mathrm{seed})$ received $(45 \pm 4.95)$ eggs (Table 1). This result is in contrast with those of Abdel Fattah and Ahmed ${ }^{[15]}$, El-Shazly, ${ }^{[25]}$ and Cheng ${ }^{[26]}$, who noticed that there is no clear relation between numbers of $C$. maculatus eggs, seed size and weight of different broad bean varieties.

Data also indicated that the lowest larval penetration rate was $93 \%$ of (A) type (Table 1). This was significantly lower $(P=0.01)$ than the other types (L, D and $\mathrm{K})$ which were $99.55 \%, 97.56 \%$ and 98.17 , respectively.

No significant correlation ( $\mathrm{r}=218, P=0.4)$ was found between larval penetration percent and seed weight (Table 1).

The correlation study also demonstrated that the larval penetration percent was inversely correlated with seed texture $(\mathrm{r}=-0.469, P=0.043$, Table 1$)$. As the larval penetration percent was relatively high (93-99.55) in the four studied varieties where seeds with wrinkled surfaces had higher larval penetration percent than seeds with smooth surfaces, it turns out that the seed coat texture did not play a role in protecting cowpeas from the beetles attack. This disagrees with Abdel Fattah and Ahmed ${ }^{[15]}$ as they found that the seed coat of faba bean was a barrier against $C$. maculatus larval penetration.

Another positive correlation was also seen in larval penetration percent with seed volume although it was not significant $(\mathrm{r}=0.91, P=0.728)$. Previous studies mentioned that the most preferred cowpea seeds, in terms of total no. of eggs, were the large-seeded cowpeas ${ }^{[2,15]}$.

Table 1: Relation between physical characters of cowpea seeds varieties and some biological aspects of cowpea weevil C. maculatus.

\begin{tabular}{|l|l|l|l|l|l|l|}
\hline $\begin{array}{l}\text { Cowpea seeds } \\
\text { varieties }\end{array}$ & $\begin{array}{l}\text { Seed texture and } \\
\text { colour }\end{array}$ & $\begin{array}{l}\text { Weight/ seed } \\
(\mathrm{g})(\text { Means } \pm \\
\text { SE. })\end{array}$ & $\begin{array}{l}\text { Volume/ seed } \\
(\mathrm{ml})(\text { Means } \pm \\
\text { SE.) }\end{array}$ & $\begin{array}{l}\text { Mean of total } \\
\text { no. of eggs/ } \\
\text { female } \pm \text { SE }\end{array}$ & $\begin{array}{l}\text { Mean no. of } \\
\text { penetrated } \\
\text { larvae } \pm \text { SE }\end{array}$ & $\begin{array}{l}\text { Larval } \\
\text { penetration \% }\end{array}$ \\
\hline Local & $\begin{array}{l}\text { slightly wrinkled } \\
\text { and creamy ( 2) }\end{array}$ & $0.129 \pm 0.004 \mathrm{~b}$ & $0.12 \pm 0.01 \mathrm{a}$ & $42.6 \pm 6.25 \mathrm{bc}$ & $42.4 \pm 6.24 \mathrm{~b}$ & 99.55 \\
\hline Dokki 331 & $\begin{array}{l}\text { wrinkled and } \\
\text { white (1) }\end{array}$ & $0.243 \pm 0.014 \mathrm{a}$ & $0.24 \pm 0.02 \mathrm{a}$ & $45 \pm 4.95 \mathrm{bc}$ & $43.75 \pm 4.42 \mathrm{~b}$ & 97.56 \\
\hline Kareem 7 & $\begin{array}{l}\text { wrinkled and } \\
\text { white (1) }\end{array}$ & $0.133 \pm 0.007 \mathrm{~b}$ & $0.1 \pm 0 \mathrm{a}$ & $58.75 \pm 5.5 \mathrm{c}$ & $57.5 \pm 9.02 \mathrm{~b}$ & 98.17 \\
\hline Aswany & $\begin{array}{l}\text { Smooth and } \\
\text { brown (3) }\end{array}$ & $0.081 \pm 0.005 \mathrm{c}$ & $0.09 \pm 0.01 \mathrm{~b}$ & $79.5 \pm 5.66 \mathrm{a}$ & $74.25 \pm 6.61 \mathrm{a}$ & 93.00 \\
\hline
\end{tabular}

N.B. Different letters indicate significant differences between varieties at the 0.05 level. Numbers between brackets indicate ranks for the correlation test.

Table 2: Different parameters used to screen the susceptibility of different cowpea seeds varieties to infestation of cowpea weevil C. maculatus.

\begin{tabular}{|c|c|c|c|c|c|c|c|c|}
\hline $\begin{array}{l}\text { Cowpea } \\
\text { seed } \\
\text { Varieties }\end{array}$ & $\begin{array}{l}\text { Total no. } \\
\text { of } \\
\text { penetrated } \\
\text { larvae }\end{array}$ & $\begin{array}{l}\text { no. of adult } \\
\text { emerged } \\
(\text { Mean } \pm \text { SE })\end{array}$ & $\begin{array}{l}\text { Adult } \\
\text { emergence } \\
\% \text { (\% AE) }\end{array}$ & $\begin{array}{l}\text { Total } \\
\text { developmental } \\
\text { time (TDT) } \\
(\text { Mean } \pm \text { SE) } \\
\text { (range) }\end{array}$ & $\begin{array}{l}\text { Growth } \\
\text { index } \\
(\mathrm{GI})\end{array}$ & $\begin{array}{l}\text { Susceptibility } \\
\text { Index (SI) }\end{array}$ & $\begin{array}{l}\text { Seed } \\
\text { moisture } \\
\text { content } \\
(\mathrm{SMC}) \\
(\text { Mean } \pm \text { SE) }\end{array}$ & $\begin{array}{l}\text { Total } \\
\text { protein } \\
\text { conc. }(\mathrm{mg} / \mathrm{g} \\
\text { tissue }) \\
(\mathrm{TPC}) \\
(\text { Mean } \pm \mathrm{SE})\end{array}$ \\
\hline Local & 10 & $\begin{array}{l}6.75 \pm 0.25 \\
b\end{array}$ & 67.5 & $\begin{array}{l}20.52 \pm 0.29 \\
(19-23) \mathrm{a}\end{array}$ & 0.20 & 88.77 & $\begin{array}{l}11.03 \pm \\
0.09 \mathrm{a}\end{array}$ & $\begin{array}{l}177.85 \pm 2.37 \\
\mathrm{a}\end{array}$ \\
\hline Dokki 331 & 10 & $9 \pm 0.71 \mathrm{a}$ & 90.42 & $\begin{array}{l}19.46 \pm 0.14 \\
(17-23) a\end{array}$ & 0.23 & 100 & $\begin{array}{l}11.71 \pm \\
0.66 \mathrm{a}\end{array}$ & $\begin{array}{l}138.72 \pm 1.38 \\
\text { c }\end{array}$ \\
\hline Kareem 7 & 10 & $5.5 \pm 0.25 b$ & 55 & $\begin{array}{l}23.39 \pm 0.22 \\
(20-28) b\end{array}$ & 0.17 & 74.09 & $\begin{array}{l}10.79 \pm \\
0.083 \mathrm{a}\end{array}$ & $\begin{array}{l}112.35 \pm 1.67 \\
d\end{array}$ \\
\hline Aswany & 10 & $\begin{array}{l}3.25 \pm 0.29 \\
\mathrm{c}\end{array}$ & 32.5 & $\begin{array}{l}25.39 \pm 0.95 \\
(20-35) b\end{array}$ & 0.13 & 59.28 & $\begin{array}{l}11.07 \pm \\
0.18 \mathrm{a}\end{array}$ & $\begin{array}{l}154.66 \pm 0.55 \\
b\end{array}$ \\
\hline
\end{tabular}

N.B. Different letters indicate significant differences between varieties at the 0.05 level. 


\section{Screening of resistance}

There was an overall significant difference in mean number of adult emergence of $C$. maculatus and total developmental time (TDT) between the four different varieties (one-way ANOVA: $\mathrm{F}_{3,15}=32.588, P=0.0$; $\mathrm{F}_{3,15}=62.414, P=0.0$ ), respectively, Table 2). The highest adult emergence \% was found to be in beetles reared on (D) (90.42) followed by (L), (K) and finally (A) cultivar $(67.5,55$ and 32.5 , respectively, Table 2). The TDT was shortest when cowpea beetles were reared on (D) cultivar was (19.46), followed by (L), (K) and finally (A) cultivar (20.52, 23.39 and 25.39, respectively, Table 2). Obiadalla et al. demonstrated that both (D) and (K) seeds were among the seeds that had high \% AE of C. maculatus and shortest TDT ${ }^{[10]}$.

Both growth index (GI) and susceptibility index (SI) were highest in beetles reared on (D) cultivar $(0.23$, 100) followed by (L) $(0.20,88.77),(\mathrm{K})(0.17,74.09)$ and finally (A) cultivar $(0.13,59.28)$ (Table 2). The current data shows that the (D) variety is the most susceptible one as the insects reared on it had the highest \% AE (90.42) combined with the shortest TDT (19.46) (Table 2), while the (A) seeds are the most resistant seeds as the larval population from this group had the lowest \% AE (32.5) combined with the longest TDT (25.39). Data available from other studies also indicate that the resistant seed varieties adversely affect bruchids by reducing adult emergence and elongating TDT $^{[2,3,10,15,27]}$.

Investigation of cowpea seeds characters revealed that the SMC was not significantly different between all varieties tested (one-way ANOVA: $P=0.335$, Table 2). At the same time SMC seemed to have no significant effect on larval penetration nor adults production $(\mathrm{r}=$ $0.210, P=0.512, \mathrm{r}=-0.04, P=0.891$, respectively), although this relationship was inversely correlated.

\section{Biochemical analysis}

\section{a) Total protein content}

Data in table (2) indicated that there was an overall significant difference in the total protein contents (TPC) of the four cowpea seeds varieties used in terms of optical density (OD) measurements (one-way ANOVA: $\mathrm{F}_{3,11}=284.352, P=0.0$, Fig. 1 ).

Table (2) shows that the TPC of (L) cowpea seeds was $177.85 \pm 2.37 \mathrm{mg} / \mathrm{g}$ tissue, while in (D) and (K) varieties the total protein decreased being, $138.72 \pm 1.38$ and $112.35 \pm 1.67 \mathrm{mg} / \mathrm{g}$ tissue, respectively. Both (D) and (K) were significantly different compared to that of (L) group (LSD test, $P=0.0$ for both, Fig. 1). The level of protein in (A) variety increased being $154.66 \pm 0.55 \mathrm{mg} / \mathrm{g}$ tissue, which was significantly different from others (LSD test, $P=0.0$ for all pairwise analysis, Fig. 1). Correlation analysis revealed that TPC have a weak positive correlation with $\% \mathrm{AE}$ and a weak negative relationship with TDT, although this correlations were not significantly different $(\mathrm{r}=0.017, P=0.957, \mathrm{r}=-$ $0.198, P=0.538$, respectively). In contrast Vir (cited by $\left.{ }^{[15]}\right)$ concluded that the cowpea genotypes with high protein content could be protected from C. maculatus attack. Abdel Fattah and Ahmed ${ }^{[15]}$ indicated also that there was a positive correlation between the total storage protein content of faba bean genotypes and the susceptibility index.

\section{b) Protein fraction}

In view of the variation observed in the resistant and susceptible type of the tested cowpea seeds varieties to $C$. maculatus infestation, seed protein profiles were analysed for detection of antinutrient compounds. Changes in the total protein profile of cowpea seeds varieties (L), (D), (K) and (A) are presented in figures (2 and 3) as well as in Tables (3, 4 and 5). Data presented in the fore mentioned figures and tables have resulted from the use of gel-pro-analysis for the SDS (PAGE) runs. The achieved results of total protein fraction were compared by electrophoretic runs of proteins extracted from (L) control cowpea seed and other varieties (D), (K) and (A) (Fig. 2). The protein fractions were separated into 33 protein banding patterns fluctuated from 23 to 31 bands. Lanes in Fig. (2) and Table 3 show nineteen identical protein bands of MW 200, 150, 100, 76.6, 70, $60,50,40,35.4,30,29.2,27.2,25,22.78,21.3,20,15$, 10 and $9.2 \mathrm{kDa}$ in all lanes representing proteins extracted from four cowpea seeds varieties. However, ten $(6.1,5.2,2.4,3.3,4.3,6.6,4.3,3.7,4.4$ and $3.9 \%$ amount) bands differ in the amount of proteins (Table 4) in spite of having the same molecular weights, being lower in the case of (L) control, (D), (K) than in case of (A). This observation may be explained by difference of the protein extracts at a quantitative level.

On reviewing the development of protein bands in all lanes, it came clear that certain bands disappear. The protein banding pattern of MW $24.3 \mathrm{kDa}$ was appeared in all cowpea seeds varieties, but was missing in the (L) cultivar (Table 3). Also, the protein fractions MW 83.907, 26.03, 16.003 with $12.347 \mathrm{kDa}$ appeared in all varieties except (A) type (Table 3). Some other protein fractions MW 90.3 and $17.07 \mathrm{kDa}$ were detected in all cowpea varieties and were missing in the (D) cultivar (Table 3).

Other protein banding patterns appeared only in two cowpea cultivars. The protein band with Rf value 0.17 was detected only in (D) and (K) varieties. The protein fraction with Rf value 0.39 appeared only in $(\mathrm{A})$ and $(\mathrm{K})$ cultivars. Another band with Rf value 0.48 appeared only in $(\mathrm{K})$ and $(\mathrm{L})$ varieties. Results of the comparative electrophoretic analysis showed also appearance of unique protein bands. The protein bands MW 123.39 and $20.37 \mathrm{kDa}$ were produced only in $(\mathrm{K})$ type, while protein fractions with MW 18.47 appeared in the (L) variety. The molecular weights are presented in Table (3) and graphically in Fig, (3) where MWt's scanned against optical densities of each protein band. The optical density of bands is shown in Table (5).

The present investigation focused on chemical composition of seed tissue which might be involved in imparting resistance of cowpeas used. This is confirmed by SDS-(PAGE) of protein fractions. 


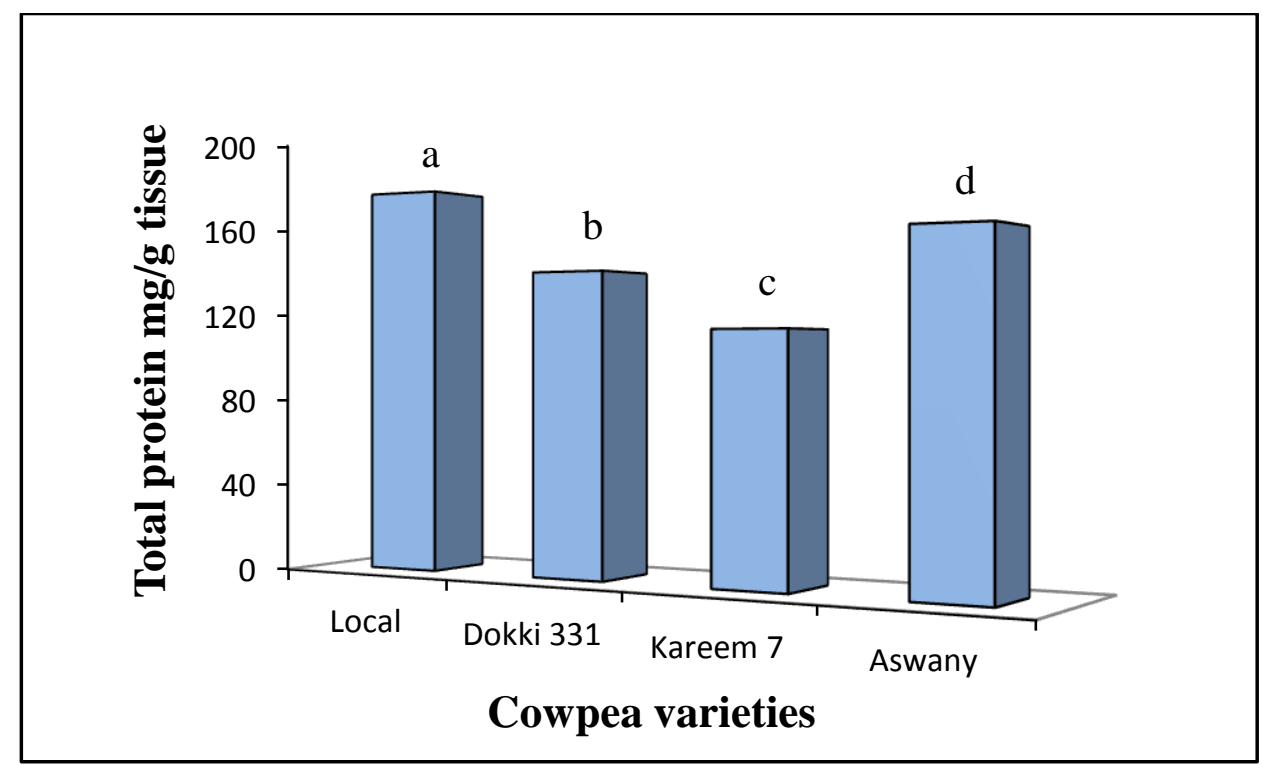

Fig. 1: A histogram showing protein concentration extracted from different cowpea seeds varieties (Local, Dokki331, Kareem7 and Aswany).

The protein profiles of different varieties varied at both the qualitative and quantitative levels. The polypeptide protein bands with MW range between 50-60 kDa were detected in both resistance and susceptible varieties with varied intensities. Protein with molecular weight approximately of $55 \mathrm{kDa}$ is a typical for vicilin subunits ${ }^{[28,29]}$. Vicilin could reduce the availability of amino acids necessary for larval growth and development ${ }^{[30]}$. The vicilin action mechanism was proposed towards $C$. maculatus ${ }^{[17,18]}$, where the capability to bind to the chitin present in the peritrophic membrane added to their lower digestibility which is likely responsible for the lethal effects of vicilins. Xavier-Filho ${ }^{[31]}$ showed that $C$. maculatus developed successfully in resistant cowpea seeds through the use of its potent enzymatic apparatus.

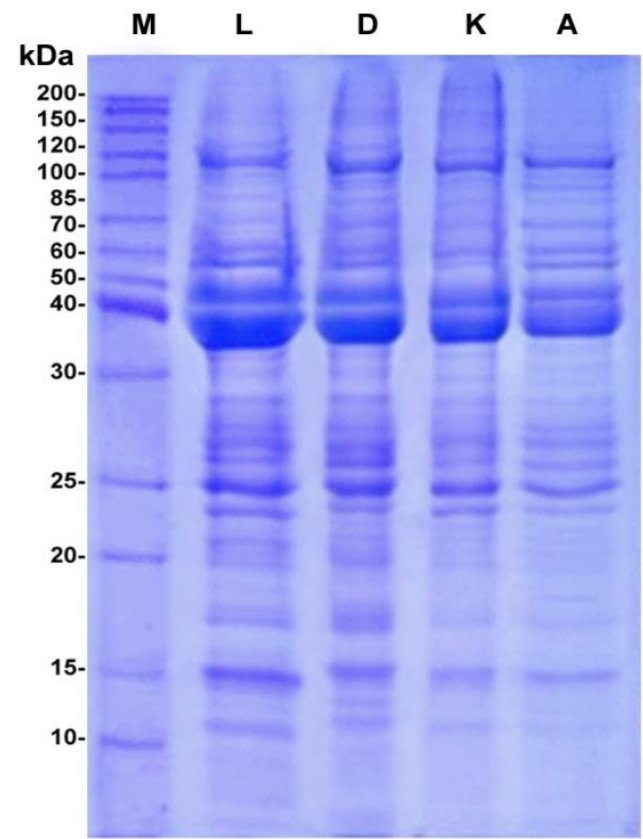

Sales et al. [17] and Abdel Fattah and Ahmed [15] recorded that low level of vicilin was hydrolysed by C.maculatus midgut enzymes and it had no clear deleterious effect either on insect development or on insect survival. The protein banding pattern with $\mathrm{MW}$ $32 \mathrm{kDa}$ was detected only in the $(\mathrm{A})$ and $(\mathrm{K})$ resistant varieties. Also, protein fraction with MW 17.69 kDa appeared in $(\mathrm{A})$ and $(\mathrm{K})$ resistant types and (L) type which was relatively susceptible. Antinutrient compounds like Lectine (30-32 kDa polypeptides) and $\alpha$-amylase inhibitors (13-17 $\mathrm{kDa}$ polypeptides) have been reported to have a role in imparing resistance to bruchids ${ }^{[15,29,32,33]}$. In addition, unique bands with MW 123.39 and $20.37 \mathrm{kDa}$ appeared only in (K) resistant cultivars.

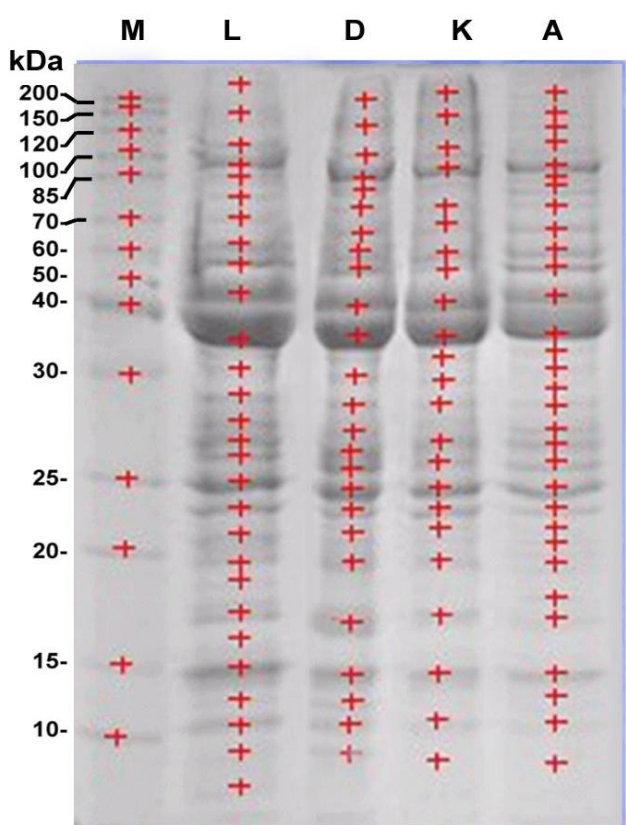

Fig. 2: (A and B) Photograph and diagrammatic illustration of electrophoretic protein pattern of local cowpea seeds (L) as a control and other types of cowpea seeds varieties Dokki331(D), Kareem7(K) and Aswany (A). M= standard molecular weight. 
These bands might have a role in reducing the performance of $C$. maculatus. Therefore, it is very important to understand the mechanism underlying the resistant cowpea varieties to improve the development of new breeding lines of cowpea seeds.
In conclusion, planting of (A) could be recommended, where it is a very promising cultivar of breeding programme for improvement of resistance, to cowpea weevil, Callosobruchus maculatus.
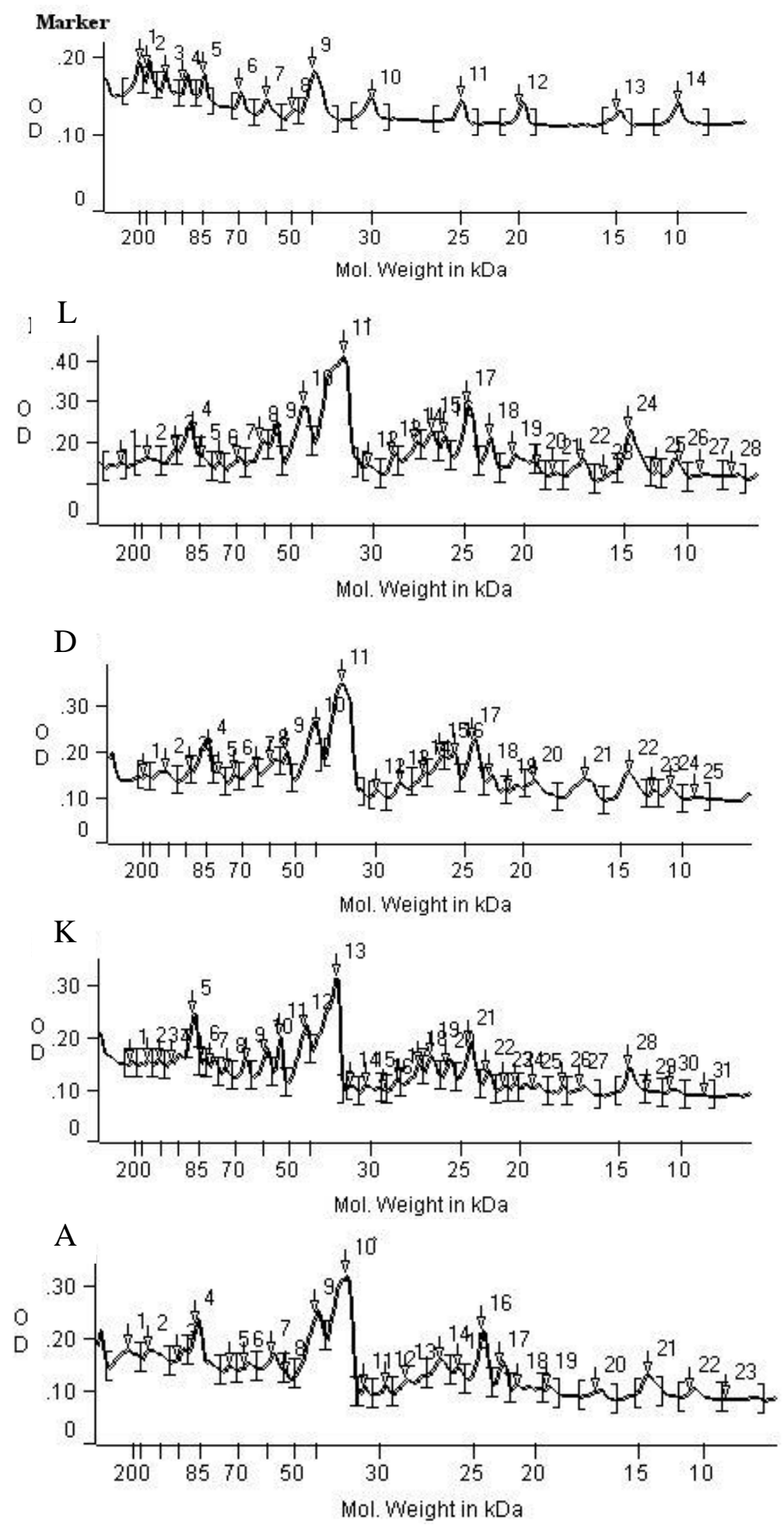

Fig. 3: Optical density (OD) of protein extracted from different cowpea seeds varieties (Local (L), Dokki331 (D), Kareem (K) and Aswany (A)) plotted against the molecular weights of protein bands from the same varieties. 
Table 3: Whole tissue protein monitoring of Local (L) and cowpea seed varieties (Dokki331 (D), Kareem7 (K) and Aswany (A)) expressed as molecular weight.

\begin{tabular}{|c|c|c|c|c|c|}
\hline varieties & $\mathrm{L}$ & D & $\mathrm{K}$ & A & Marker \\
\hline Rows & (mol.w.) & (mol.w.) & (mol.w.) & (mol.w.) & (mol.w.) \\
\hline 1 & 323.04 & 200 & 242.28 & 242.28 & 200 \\
\hline 2 & 141.86 & 126.88 & 141.86 & 137.96 & 150 \\
\hline 3 & & & 123.39 & & 120 \\
\hline 4 & 105.35 & 97.989 & 108.13 & 102.64 & 100 \\
\hline 5 & 90.341 & & 90.341 & 88.525 & \\
\hline 6 & 83.907 & 83.907 & 83.907 & & 85 \\
\hline 7 & & 79.673 & 80.711 & & \\
\hline 8 & 76.639 & 73.72 & 73.72 & 73.72 & \\
\hline 9 & 70 & 65.263 & 66.184 & 68.065 & 70 \\
\hline 10 & 61.705 & 60 & 60 & 58.916 & 60 \\
\hline 11 & 54.772 & 53.783 & 53.783 & 52.811 & 50 \\
\hline 12 & 44.17 & 40 & 43.089 & 41.004 & 40 \\
\hline 13 & 34.641 & 35.482 & 35.482 & 35.059 & \\
\hline 14 & & & 33.019 & 32.237 & \\
\hline 15 & 30.728 & 30 & 30.728 & 29.698 & 30 \\
\hline 16 & 28.955 & 28.518 & 29.25 & 28.518 & \\
\hline 17 & 27.665 & & 28.374 & & \\
\hline 18 & 26.701 & 27.248 & 27.248 & 26.701 & \\
\hline 19 & 26.034 & 26.299 & 26.566 & & \\
\hline 20 & 24.769 & 25.512 & 25.771 & 25.771 & 25 \\
\hline 21 & & 24.312 & 24.312 & 24.312 & \\
\hline 22 & 22.78 & 22.78 & 22.78 & 22.78 & \\
\hline 23 & 20.952 & 21.147 & 21.345 & 21.345 & \\
\hline 24 & & & 20.375 & & \\
\hline 25 & 19.294 & 19.433 & 19.294 & 19.433 & 20 \\
\hline 26 & 18.479 & & & & \\
\hline 27 & 17.073 & & 17.698 & 16.951 & \\
\hline 28 & 16.003 & 16.709 & 16.829 & & \\
\hline 29 & 14.759 & 14.288 & 14.288 & 14.288 & 15 \\
\hline 30 & 12.347 & 12.347 & 12.549 & & \\
\hline 31 & 10.67 & 10.845 & 10.845 & 11.022 & 10 \\
\hline 32 & 9.2211 & 9.2211 & 8.6419 & 8.7832 & \\
\hline 33 & 7.5903 & & & & \\
\hline
\end{tabular}


Table 4: Percent concentrations and relative fragmentation of protein fractions of control (L) and other types of cowpea seeds varieties (Dokki331 (D), Kareem7 (K) and Aswany (A)).

\begin{tabular}{|c|c|c|c|c|c|c|c|c|c|}
\hline Varieties & $\mathrm{L}$ & $\mathrm{L}$ & D & D & $\mathrm{K}$ & $\mathrm{K}$ & A & A & Marker \\
\hline Rows & \%amount & (Rf.) & \%amount & (Rf.) & \%amount & (Rf.) & \%amount & (Rf.) & \%amount \\
\hline 1 & 2.9414 & 0.0346 & 1.91 & 0.0538 & 2.1983 & 0.0462 & 6.1081 & 0.0462 & 4.4722 \\
\hline 2 & 3.8974 & 0.0731 & 4.2956 & 0.0885 & 2.6635 & 0.0731 & 5.2627 & 0.0769 & 2.5938 \\
\hline 3 & & & & & 2.2141 & 0.0923 & & & 4.2699 \\
\hline 4 & 2.2301 & 0.115 & 2.3001 & 0.127 & 4.134 & 0.112 & 3.2891 & 0.119 & 3.2862 \\
\hline 5 & 4.1286 & 0.142 & & & 3.1173 & 0.142 & 6.4329 & 0.146 & \\
\hline 6 & 1.7751 & 0.158 & 4.4923 & 0.158 & 1.358 & 0.158 & & & 3.2229 \\
\hline 7 & & & 1.9801 & 0.173 & 2.2061 & 0.169 & & & \\
\hline 8 & 1.6263 & 0.185 & 1.8559 & 0.196 & 1.9747 & 0.196 & 2.4369 & 0.196 & \\
\hline 9 & 2.6792 & 0.212 & 3.2704 & 0.231 & 3.2345 & 0.227 & 3.3261 & 0.219 & 3.6395 \\
\hline 10 & 3.5426 & 0.246 & 3.9675 & 0.254 & 3.4566 & 0.254 & 4.3415 & 0.258 & 4.2627 \\
\hline 11 & 2.8052 & 0.273 & 2.3476 & 0.277 & 2.7012 & 0.277 & 1.4649 & 0.281 & 2.6006 \\
\hline 12 & 6.176 & 0.312 & 6.342 & 0.327 & 4.9574 & 0.315 & 6.6133 & 0.323 & 6.8615 \\
\hline 13 & 12.397 & 0.373 & 10.427 & 0.365 & 8.7753 & 0.365 & 8.7933 & 0.369 & \\
\hline 14 & & & & & 1.5387 & 0.388 & 1.4438 & 0.396 & \\
\hline 15 & 2.1545 & 0.412 & 1.9847 & 0.419 & 2.7183 & 0.412 & 2.2971 & 0.427 & 5.7277 \\
\hline 16 & 2.3272 & 0.446 & 3.3912 & 0.458 & 0.58322 & 0.438 & \begin{tabular}{|l|}
4.3262 \\
\end{tabular} & 0.458 & \\
\hline 17 & 3.5652 & 0.481 & & & 1.9359 & 0.462 & & & \\
\hline 18 & 3.2476 & 0.508 & 2.2626 & 0.492 & 3.3383 & 0.492 & 3.7191 & 0.508 & \\
\hline 19 & 2.1868 & 0.527 & 3.1602 & 0.519 & 2.9898 & 0.512 & & & \\
\hline 20 & 5.3874 & 0.562 & 2.8969 & 0.542 & 2.479 & 0.535 & 2.3606 & 0.535 & 6.5068 \\
\hline 21 & & & 4.7664 & 0.569 & 4.3303 & 0.569 & 4.5786 & 0.569 & \\
\hline 22 & 3.1128 & 0.596 & 3.0506 & 0.596 & 2.114 & 0.596 & 2.634 & 0.596 & \\
\hline 23 & 4.8412 & 0.631 & 2.5351 & 0.627 & 1.5239 & 0.623 & 3.9716 & 0.623 & \\
\hline 24 & & & & & 1.261 & 0.642 & & & \\
\hline 25 & 1.226 & 0.669 & 4.0693 & 0.665 & 3.7004 & 0.669 & 1.7741 & 0.665 & 5.3567 \\
\hline 26 & 1.9361 & 0.692 & & & & & & & \\
\hline 27 & 3.9407 & 0.735 & & & 2.3358 & 0.715 & 3.7354 & 0.738 & \\
\hline 28 & 2.4154 & 0.769 & 5.9005 & 0.746 & 3.7414 & 0.742 & & & \\
\hline 29 & 5.1541 & 0.808 & 5.4324 & 0.815 & 3.9928 & 0.815 & 3.5952 & 0.815 & 4.2588 \\
\hline 30 & 1.1476 & 0.85 & 1.4651 & 0.85 & 1.9971 & 0.846 & & & \\
\hline 31 & 3.37 & 0.885 & 2.8942 & 0.881 & 2.5711 & 0.881 & 4.4928 & 0.877 & 7.7652 \\
\hline 32 & 3.7872 & 0.919 & 2.8665 & 0.919 & 3.1735 & 0.933 & 3.9463 & 0.93 & \\
\hline 33 & 2.405 & 0.963 & & & & & & & \\
\hline Sum & 96.404 & & 89.864 & & 89.315 & & 90.944 & & 64.825 \\
\hline In Lane & 100 & & 100 & & 100 & & 100 & & 100 \\
\hline
\end{tabular}


Table 5: Optical density of protein fractions of control (L) and other types of cowpea seeds varieties (Dokki331 (D), Kareem7 (K) and Aswany (A)).

\begin{tabular}{|c|c|c|c|c|c|}
\hline Varieties & $\mathrm{L}$ & $\mathrm{D}$ & $\mathrm{K}$ & A & Marker \\
\hline Rows & $(\max O D)$ & $(\max O D)$ & $(\max O D)$ & $(\max O D)$ & $(\max O D)$ \\
\hline 1 & 0.15015 & 0.14764 & 0.15317 & 0.18244 & 0.19319 \\
\hline 2 & 0.16289 & 0.15843 & 0.15749 & 0.17921 & 0.1865 \\
\hline 3 & & & 0.15523 & & 0.17344 \\
\hline 4 & 0.183 & 0.16166 & 0.15263 & 0.16257 & 0.16682 \\
\hline 5 & 0.21737 & & 0.24321 & 0.22601 & \\
\hline 6 & 0.16331 & 0.19938 & 0.15836 & & 0.1785 \\
\hline 7 & & 0.15361 & 0.14584 & & \\
\hline 8 & 0.14831 & 0.15425 & 0.1356 & 0.14953 & \\
\hline 9 & 0.1638 & 0.16488 & 0.15619 & 0.15063 & 0.15674 \\
\hline 10 & 0.2064 & 0.17682 & 0.17215 & 0.16846 & 0.14609 \\
\hline 11 & 0.21524 & 0.20363 & 0.20297 & 0.13121 & 0.13152 \\
\hline 12 & 0.28946 & 0.24636 & 0.21785 & 0.24701 & 0.18346 \\
\hline 13 & 0.41188 & 0.35004 & 0.31364 & 0.32042 & \\
\hline 14 & & & 0.10914 & 0.11062 & \\
\hline 15 & 0.14453 & 0.11682 & 0.10998 & 0.11196 & 0.14265 \\
\hline 16 & 0.16967 & 0.13243 & 0.0983 & 0.12607 & \\
\hline 17 & 0.20006 & & 0.11548 & & \\
\hline 18 & 0.22518 & 0.15745 & 0.15021 & 0.16094 & \\
\hline 19 & 0.2175 & 0.19412 & 0.16718 & & \\
\hline 20 & 0.29254 & 0.19084 & 0.14704 & 0.14687 & 0.14629 \\
\hline 21 & & 0.22625 & 0.18827 & 0.21715 & \\
\hline 22 & 0.21269 & 0.1489 & 0.1333 & 0.14967 & \\
\hline 23 & 0.16884 & 0.11638 & 0.10932 & 0.11016 & \\
\hline 24 & & & 0.10897 & & \\
\hline 25 & 0.14136 & 0.13983 & 0.10657 & 0.10787 & 0.13718 \\
\hline 26 & 0.12706 & & & & \\
\hline 27 & 0.15503 & & 0.10861 & 0.10153 & \\
\hline 28 & 0.11461 & 0.14054 & 0.10701 & & \\
\hline 29 & 0.23276 & 0.15563 & 0.14382 & 0.13315 & 0.12987 \\
\hline 30 & 0.1321 & 0.11759 & 0.09774 & & \\
\hline 31 & 0.14926 & 0.1225 & 0.10287 & 0.10168 & 0.14145 \\
\hline 32 & 0.12532 & 0.1029 & 0.09058 & 0.08767 & \\
\hline 33 & 0.12234 & & & & \\
\hline \multicolumn{6}{|l|}{ Sum } \\
\hline In Lane & & & & & \\
\hline
\end{tabular}




\section{References}

1) Chauhan, Y.S. and Ghaffar, M.A. (2002). Solar heating of seeds- a low cost method to control bruchid (Callosobruchus spp.) attack during storage of pigeonpea. J. Stored Prod. Res., 38: 87-91.

2) Jackai, L.E.N. and Asante, S.K. (2003). A case for the standardization of protocols used in screening cowpea, Vigna unguiculata for resistance to Callosobruchus maculatus (Fabricius) (Coleoptera: Bruchidae). J. Stored Prod. Res., 39: 251-263.

3) Appleby, J.H. and Credland, P.F. (2004). Environmental conditions affect the response of West African Callosobruchus maculatus (Coleoptera: Bruchidae) populations to susceptible and resistant cowpeas. J. Stored Prod. Res., 40: 269287.

4) Moravvej, G. and Abbar, S. (2008). Fumigant Toxicity of citrus oils against cowpea seed beetle Callosobruchus maculatus (F.) (Coleoptera: Bruchidae). Pak. J. Biol. Sci., 11(1): 48-54.

5) Lale, N.E.S. (1998). Preliminary studies on the effect of solar heat on oviposition, development and adult mortality of the cowpea bruchid Callosobruchus maculates (F.) in the Nigerian savanna. J. Arid Environ., 40: 157 - 162.

6) Ali, M.A.M., El-Sayed, F. M.A. and El-Bishlawy, H.M.I. (2005). Impact of initial population densities of cowpea beetle, Callosobruchus maculatus (F.) and legume seeds on insects development, seed damage, food consumption and weight losses of cowpea and faba bean seeds. Egypt. J. Agric. Res., 83(2): 609-623.

7) Aly, M.A.M., El-Sayed, F.M.A. and El-Bishlawy, H.M.I. (2005). Damage and quantitative loss caused by Callosobruchus maculatus (Coleoptera: Bruchidae) to some cowpea and faba bean varieties. Egypt. J. Agric. Res., 83(2): 563-581.

8) El-sayed, F.M.A., Ali, M.A.M. and El-Bishlawy, H.M.I. (2005). Infestation potential of Callosobruchus maculatus (F.) on some cowpea and faba bean varieties. Egypt. J. Agric. Res., 83(2): 583-593.

9) Lephale, S., Addo-Bediako, A. and Ayodele, V. (2012). Susceptibility of seven cowpea cultivars (Vigna unguiculata) to cowpea beetle (Callosobruchus maculates). Agric. Sci. Res. J., 2 (2): $65-69$.

10) Obiadalla- Ali, .H.A., Salman, A.M.A. and ElHady, M.A.H.A. (2007). Screening some local and introduced cowpea cultivars for dry-seed yield and resistance to Callosobruchus maculatus (F.). Annals Agric. Sci., 52(1): 197-212.

11) Obopile, M., Masiapeto, K. and Gwafila, C. (2011). Variation in reproductive and developmental parameters of Callosobruchus maculatus (F) reared on ten Botswana cowpea landraces. Afr. J. Biotechnol., 10 (63): 13924-13928.
12) Mekasha, C., Dzolkifli, O., Yusuf, S., Rita, M. and Noorma, O. (2006). Short communication development of efficient solar heaters for storage insect pest management. Afr. Crop Sci. J., 14(3): 253-261.

13) Thorpe, G.R. (1998). The modelling and potential applications of a simple solar regenerated grain cooling device. Postharvest Biol. Technol., 13 (2): 151-168.

14) Velten, G., Rott, A.N., Cardona, C. and Dorn, S. (2007). Effects of a plant resistance protein on parasitism of the common bean bruchid Acanthoscelides obtectus (Coleoptera: Bruchidae) by its natural enemy Dinarmus basalis (Hymenoptera: Pteromalidae). Biol. Cont., 43:78-84.

15) Abdel Fattah, H.M. and Ahmed, S.M. (2007). Physical and biochemical Characteristics of some resistant faba bean genotypes in relation to Callosobruchus maculatus infestation. J. Egypt. Acad. Soc. Environ. Develop., 8(3): 37-44.

16) Sales, M.P., Gerhardt, I.R., Grossi-de-Sá, M.F. and Xavier-Filho, J. (2000). Do legume storage proteins play a role in defending seeds against Bruchids?. Plant Physiol., 124: 515-522.

17) Sales, M.P., Pimenta, P.P., Paes, N.S., Grossi-de-Sá, M.F. and Xavier-Filho, J. (2001).Vicilins (7S storage globulins) of cowpea (Vigna unguiculata) seeds bind to chitinous structures of the midgut of Callosobruchus maculatus (Coleoptera: Bruchidae) larvae. Braz. J. Med. Biol. Res., 34: 27-34.

18) Sales, M.P., Andrade, L.B.S., Ary, M.B., Miranda, M.R. A., Teixeira, F.M., Oliveir, A.S., Fernands, K.V.S. and Xavier-Filho, J. (2005). Performance of bean bruchids Callosobruchus maculatus and Zabrotes Subfasciatus (Coleoptera: Bruchidae) reared on resistant (IT8ID-1045) and susceptible (Epace 10) Vigna unguiculata seeds: Relationship with trypsin inhibitor and vicilin excretion. Comp. Biochem. Physiol., 142: 422-426.

19) Thakur, D. and Banyal, H.S. (2005). Development and larval morphology of Callosobruchus theobromae (Coleoptera: Bruchidae). Pol. pis. entomol., 74: 61-72.

20) Agrawal, P.K. (1993). Hand book of seed testing, Dept. of Agricultural and co-operation, Ministry of Agriculture, Govt. of India, Newdelhi, 104-115.

21) Bradford, M.M. (1976). A rapid and sensitive method for the quantitation of microgram quantities of protein utilizing the principle of protein-dye binding. Anal. Biochem., 72: 248-254.

22) Mohamed, M.I. (1990). Sterility and some associated physiological changes in the adult cowpea weevil, Callosobruchus maculatus. Ph. D. Ain-shams University.

23) Smith, I. (1976). Chromatographic and electrophoretic techniques. Zone electrophoresis, vol. $24^{\text {th }}$ Ed. William Heiemann Medocal Book 5, London. 
24) Sulehrie, M.A.Q., Golob, P., Tran, B.M.D. and Farrell, G. (2003). The effect of attributes of Vigna spp. On the bionomics of Callosobruchus maculatus. Entomol. Exp. Appl., 106: 159-168.

25) El-Shazly, E.A. (1998). Relationship between physical characteristics and susceptibility to Callosobruchus maculatus in broad bean, Vicia Faba varieties. Bull. Entomol. Soc. Egypt., 25: 127135.

26) Cheng, I.C., Rouling, Y. and Shwu, B.H. (2003). Interactions between host preference and offspring survivorship of Callosobruchus maculatus (Fab.). Formosan Entomol., 23: 291-303.

27) Ofuya, T.I. and Credland, P.F. (1995). Responses of three populations of the seed beetle, Callosobruchus maculatus (F.) (Coleoptera: Bruchidae), to seed resistance in selected varieties of cowpea, Vigna unguiculata (L.)Walp. J. Stored Prod. Res., 31(1): 17-27.

28) Pedalino, M., Paino-d' Urzo, M., Delle Done, G., Grillo S. and Rao, R. (1992). The structure of cowpea (Vigna unguiculata L. Walp) seed storage proteins. Seed Sci. Technol., 20: 223-231.
29) Macedo, M.R.L., Andrade, L.B.S., Moraes, R.A. and Xavier-Filho, J. (1993). Vicilin variants and the resistance of cowpea (Vigna unguiculata) seeds to the cowpea weevil (Callosobruchus maculatus). Comp. Biochem. Physiol., 105C: 89-94.

30) Casey, R., Domeney, C. and Ellis, N. (1986). Legume storage proteins and their genes. In: Miflin, B.J. (Editor), Oxford Surveys of Plant Molecular Biology and Cell Biology. Vol. 3. Oxford University Press, Oxford, 1-95.

31) Xavier-Filho, J. (1991). The resistance of seeds of cowpea (Vigna unguiculata) to the cowpea weevil (Callosobruchus maculatus). Meórias do Instituto Oswaldo Cruz, 86: 75-77.

32) Fory, L.F., Finhadi-Filho, F., Quintero, C.M., Osborn, T.C., Cardona, C., Chrispeels, M.J. and Mayer, L. (1996). Alpha amylase inhibitors in resistance to common beans to Mexican bean weevil (Coleoptera: Bruchidae). J. Econ. Entomol., 89: 204210.

33) Ignacimuthu, S., Janarthanan, S. and Balachandran, B. (2000). Chemical basis of resistance in pulses to Callosobruchus maculatus (F.) (Coleoptera: Bruchidae). J. Stored Prod. Res., 36: 89-99. 